\title{
Pelatihan Optimalisasi Pembelajaran Daring Berbasis Google Classroom di Era Covid - 19 Bagi Guru MGMP IPA Kota Palembang
}

\author{
Didi Jaya Santri ${ }^{1}$, Susy Amizera ${ }^{2 *}$, Mgs. Mhd Tibrani ${ }^{3}$, Riyanto ${ }^{4}$, \\ Ermayanti $^{5}$ \\ ${ }^{12345}$ Universitas Sriwijaya \\ E-mail: susyamizera@fkip.unsri.ac.id
}

\begin{tabular}{l}
\hline Article History: \\
Received: Oktober \\
2021 \\
Revised: November \\
2021 \\
Accepted: November \\
2021 \\
Available online: \\
Desember 2021
\end{tabular}

Keywords: Google

Classroom,

Pembelajaran Daring,

Media Pembelajaran
Abstract:
Pembelajaran Virtual merupakan perubahan sistem pembelajaran yang terdampak karena pandemi Covid-19. Oleh karena itu, dibutuhkan sarana berupa media elektronik untuk memfasilitasi kondisi tersebut. Peningkatan kualitas kompetensi guru sangat penting untuk meningkatkan kualitas pembelajaran terutama pada pelaksanaan kegiatan pembelajaran di masa pandemi. Oleh sebab itu, diharapkan melalui pelatihan terkait pembelajaran daring, maka diharapkan juga guru akan mampu mengembangkan kompetensi dalam pemanfaatan google class room sebagai media pembelajaran daring. Model kegiatan yang akan dilaksanakan yaitu model pendampingan yang ditujukan kepada guru IPA kota Palembang. Metode yang ditempuh dalam kegiatan ini meliputi presentasi materi dan praktik penggunaan google classroom dalam pelaksanaan pembelajaran daring. Berdasarkan kegiatan pengabdian masyarakat ini dapat disimpulkan bahwa kegiatan pelatihan ini peserta pelatihan yaitu guru - guru MGMP IPA Kota Palembang dapat meningkatkan kompetensi mereka dalam upaya merancang pembelajaran daring berbasis google classroom. Melalui pelatihan ini, guru - guru lebih memahami fungsi fitur - fitur yang terdapat dalam google classroom. Dengan demikian guru - guru 


\section{Pendahuluan}

Sistem pembelajaran daring merupakan pembelajaran yang memanfaatkan kecanggihan teknologi internet dimana proses pengajaran terjadi secara terpisah dari proses belajar sehingga komunikasi antara guru dan siswa harus difasilitasi media elektronik. Perubahan sistem pembelajaran tersebut merupakan dampak dari pandemi Covid-19 yang menyebabkan pembelajaran dialihkan menjadi sistem virtual (Mar'ah, et.al., 2020). Oleh karena itu, dibutuhkan sarana berupa media elektronik untuk memfasilitasi kondisi tersebut.

Media elektronik yang dapat digunakan untuk melaksanakan pembelajaran daring yaitu menggunakan software teknologi informasi (Salsabila, et.al., 2020). Hal ini berimplikasi pada peningkatan jumlah software yang disediakan oleh perusahaan digital. Namun demikain peningkatan software teknologi informasi harus berbanding lurus dengan meningkatkannya kemampuan pengguna software teknologi tersebut. Menurut Ningsih, et.al (2020), guru sebagai pengguna harus mampu meningkatkan kompetensi utuk menggunakan teknologi informasi dalam kegiatan pembelajaran.

Google classroom merupakan salah satu produk media pembelajaran yang dikembangkan oleh google. Google classroom telah dirancang sebagai media yang dapat mempermudah guru dalam pelaksanaan pembelajaran daring karena melalui media ini dapat membantu guru untuk memonitoring kegiatan peserta didik pada proses pembelajaran (Sabran dan Sabara, 2019). Penggunaan google classroom sebagai media pembelajaran online memiliki banyak keuntungan terutama bagi pemula yang belum mahir dalam pengelolaan IT. Fitur pada aplikasi google classroom sangat sederhana dan lengkap sehingga guru lebih mudah mempelajari penggunaan aplikasi google classroom dibandingkan dengan media learning management system (LMS) lainnya (Harefa dan Sumiyati, 2020). Hal ini dapat mempermudah guru dalam 
mengoperasikan fitur yang ada di google classroom Google Classroom lebih sederhana dan mudah untuk digunakan, sehingga ideal bagi guru meskipun dengan kemampuan penguasaan IT yang beragam.

Namun demikian, masih banyak guru yang belum memiliki kemampuan dalam penggunaan sebagai media pembelajaran daring walaupun google classroom telah menawarkan fitur yang cukup lengkap untuk mendukung pembelajaran tersebut (Soni, et.al., 2018). Hal ini sejalan dengan hasil data pendahuluan yang dilakukan kepada guru IPA di kota Palembang mengenai sistem pembelajaran virtual, diperoleh data bahwa guru - guru masih belum memahami cara pemanfaatan media pembelajaran virtual khususnya google classroom dan berdasarkan hasil kuesioner diperoleh data bahwa 73,93\% guru IPA di kota Palembang belum pernah mengikuti pelatihan pengelolaan pembelajaran daring. Padahal di sisi lain, peningkatan kualitas kompetensi guru sangat penting untuk meningkatkan kualitas pembelajaran terutama pada pelaksanaan kegiatan pembelajaran di masa pandemi (Munir, 2009). Oleh sebab itu, diharapkan melalui pelatihan terkait pembelajaran daring, maka diharapkan juga guru akan mampu mengembangkan kompetensi dalam pemanfaatan google classroom sebagai media pembelajaran daring.

\section{Metode}

Model kegiatan yang akan dilaksanakan yaitu model pendampingan yang ditujukan kepada guru IPA kota Palembang untuk meningkatkan keterampilan mereka dalam merancang pembelajaran daring melalui google classroom. Metode yang ditempuh dalam kegiatan ini meliputi presentasi materi dan praktik penggunaan google classroom dalam pelaksanaan pembelajaran daring, yang diawali pengenalan tampilan dan fitur - fitur yang terdapat pada google classroom. pada Hal lain yang akan dilakukan adalah pelatihan dan penugasan pada para peserta, dalam rangka efektivitas dan efisiensi kegiatan maka kegiatan dilakukan dalam tiga tahap yaitu

1) Tahap pertama, seluruh peserta mengikuti kegiatan klasikal berupa presentasi materi dari tim pelatihan mengenai informasi secara umum tentang google classroom, macam - macam fitur dan fungsinya pada 
google classroom, cara menggunakan fitur - fitur pada google claaroom baik melalui Laptop maupun mobile phone dan cara merancang pembelajaran dari melalui google classroom.

2) Tahap kedua, kegiatan pendampingan pembuatan rancangan pembelajaran daring menggunakan google classroom yang diawali dengan menentukan materi pembelajaran yang disesuaikan dengan Kompetensi Dasar kegiatan pembelajaran yang sebelumnya telah dipersiapkan oleh guru

3) Tahap ketiga, setelah peserta mengirimkan rancangan kegiatan pembelajaran menggunakan google classroom

Adapun tahap - tahap pelaksanaan pengabdian dapat dilihat pada gambar. 1

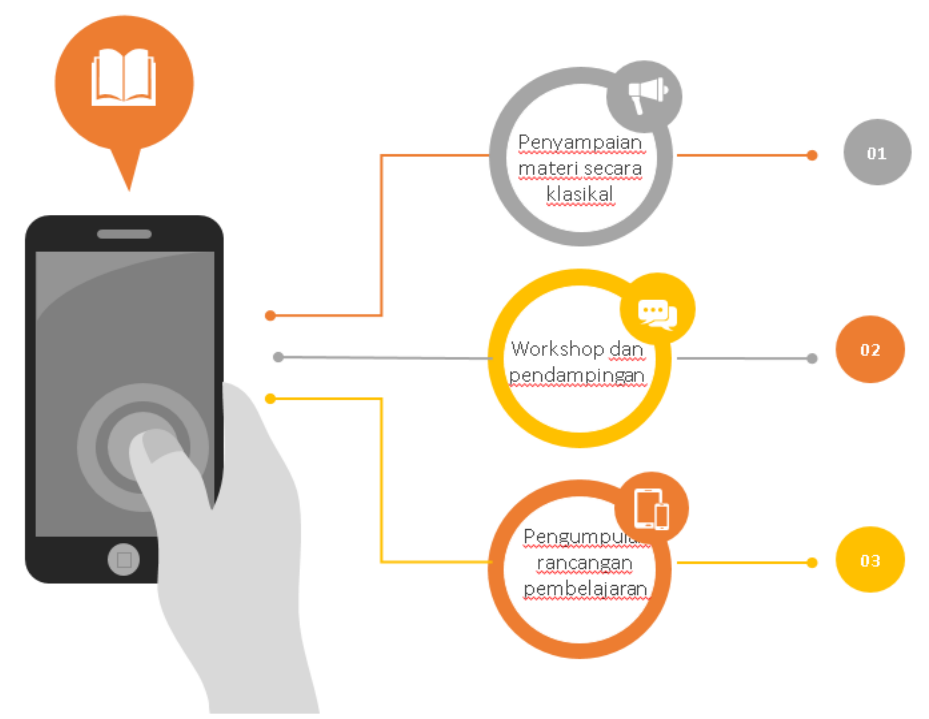

Gambar 1. Tahap Pelaksanaan Pengabdian

Untuk mengetahui keberhasilan pelatihan ini digunakan tes dan angket respon peserta terhadap kegiatan pelatian. Tes diberikan sebelum pelaksanaan pelatihan (tes awal) dan setelah selesai kegiatan (tes akhir). Tes awal untuk menjajaki pengetahuan dan kemampuan awal peserta mengenai pembelajaran 
daring berbasis google classroom, Sedangkan tes akhir untuk mengetahui pemahaman dan kemampuan peserta setelah diberi penyuluhan dan pelatihan. Lembar respon peserta untuk mengetahui feedback peserta terhadap kegiatan pelatihan.

\section{Hasil}

Kegiatan pengabdian ini dilakukan secara daring melalui zoom meeting dan Grup WhatsApp. Pelaksanaan dilakukan mulai tanggal 16 Juni 2021 sampai dengan 09 September 2021. Pelaksanaan kegiatan dilakukan dengan beberapa tahapan, yaitu tahap penyampaian materi secara klasikal yang dilaksanakan melalui zoom meeting, tahap pendampingan pembuatan rancangan kegiatan pembelajaran berbasis google classroom dan tahap pengumpulan rancangan pembelajaran daring berbasis google classroom melalui grup whatsApp serta evaluasi untuk mengetahui effektivitas kegiatan pelatihan.

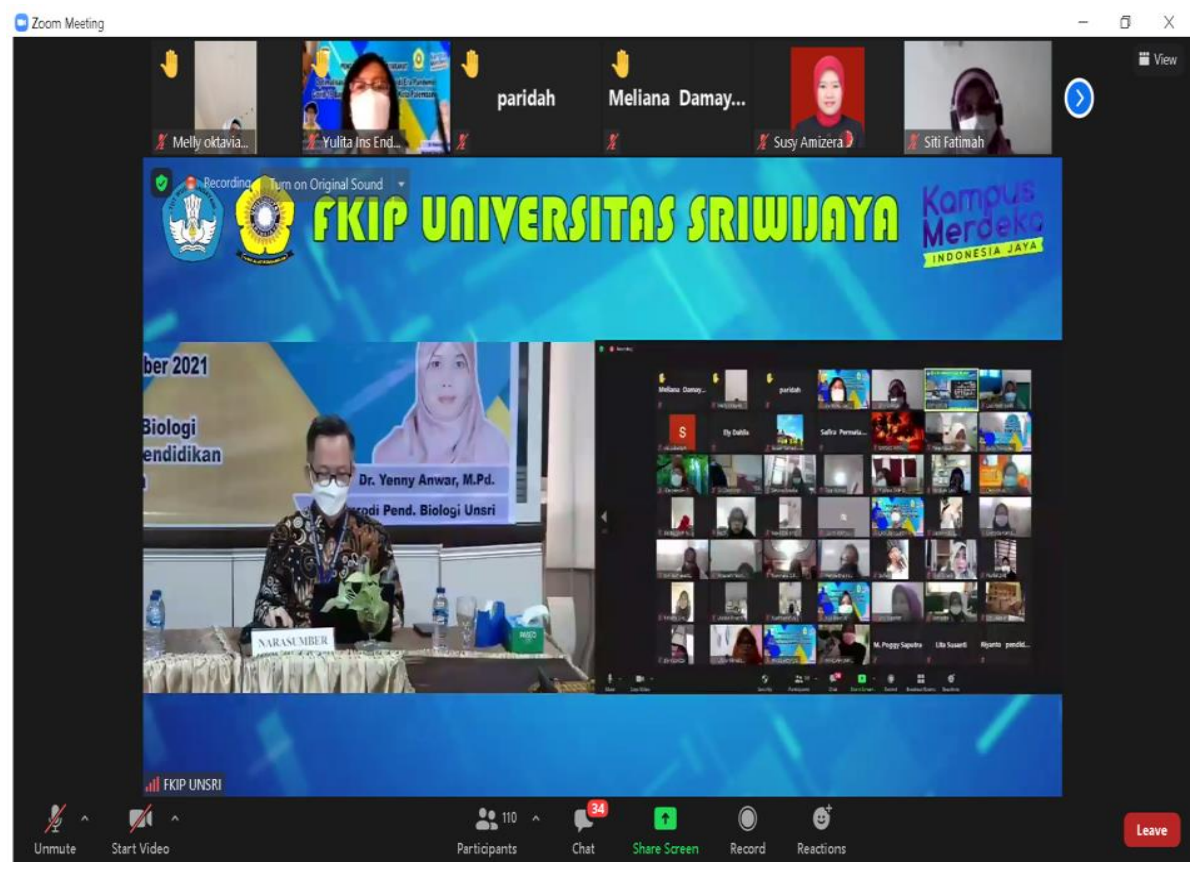

Gambar 2. Penyampaian Materi secara Klasikal 
Pada tahap penyampaian materi, peserta pelatihan diberikan informasi mengeai panduan menggunakan google classroom. Informasi tersebut meliputi cara pembuatan akun google classroom dan perkenalan fitur - fitur yang terdapat pada google classroom serta fungsi dari fitur - fitur tersebut. Selanjutnya, peserta diberikan kesempatan untuk latihan membuat kelas, menambahkan siswa dalam kelas dan membuat aktivitas pada google classroom.

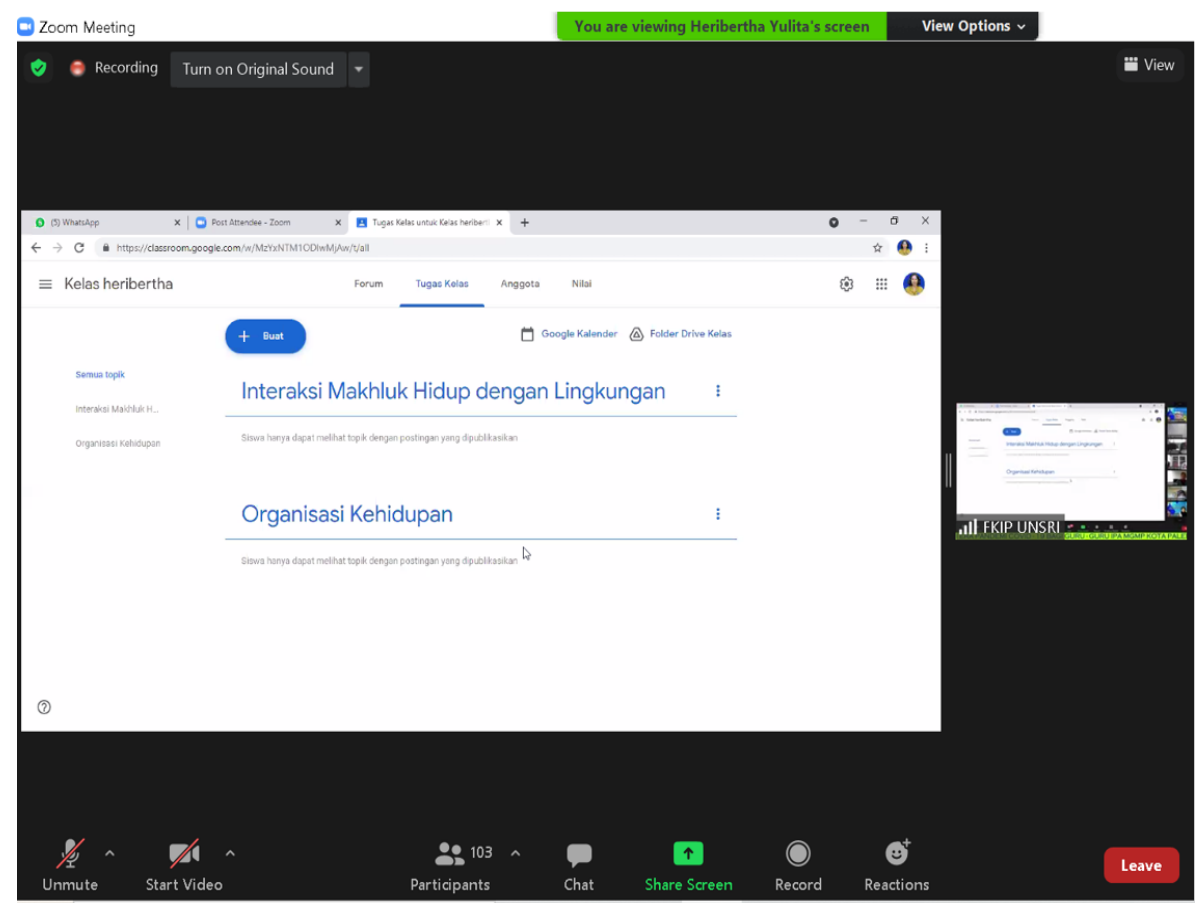

Gambar 3. Latihan Pembuatan aktivitas kelas melalui google classroom

Tahap selanjutnya, peserta pelatihan diberikan pendampingan untuk membuat rancangan pembelajaran dari berbasis google classroom secara melalui tugas mandiri (asinkrounous). Narasumber memberikan bimbingan kepada peserta melalui grup Whatss App. Rancangan pembelajaran daring meliputi materi ajar, tugas / latihan dan daftar hadir peserta didik. 


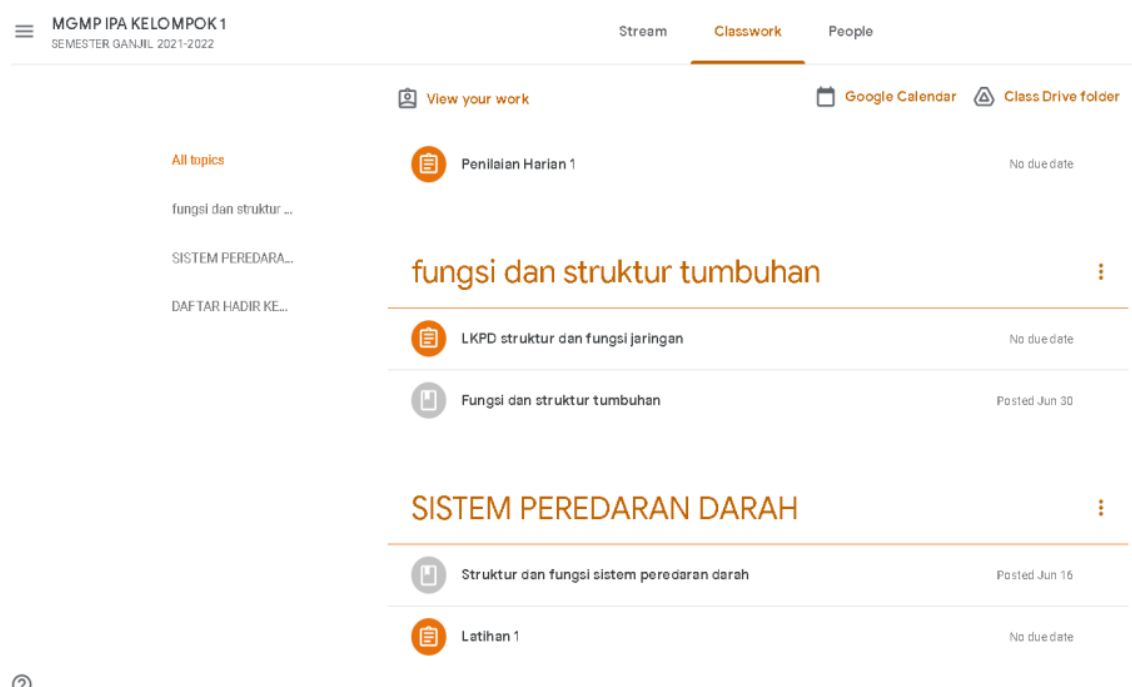

Gambar 3. Rancangan Pembelajaran Daring Berbasis Google Classroom

Gambaran mengenai effektivitas pelatihan dapat terlihat melalui hasil prestes dan post test serta respon peserta setelah dilaksanakan kegiatan pelatihan dan pendampingan pembuatan rancangan pembelajaran daring berbasis google form. Rata - rata hasil pretest dan post test dapat terlihat pada gambar 1

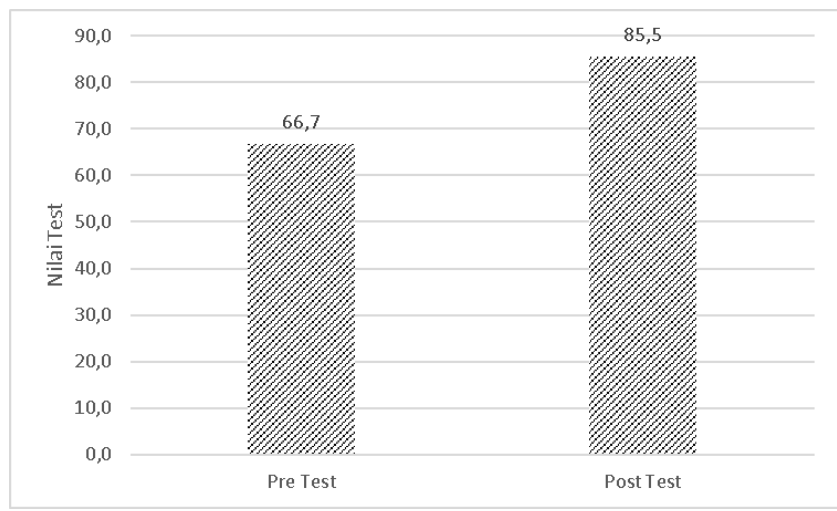

Gambar 4. Rata - Rata Hasil Pre Test dan Post Test

Selanjutnya, respon peserta pelatihan dapat dilihat melalui tabel 1 
Tabel. 1 Respon Peserta terhadap Pembelajaran Daring Berbasis Google Classroom

\begin{tabular}{lllll}
\hline Pertanyaan & SS & S & TS & STS \\
\hline $\begin{array}{l}\text { Pelatihan mengenai pemanfaatan fitur Google } \\
\begin{array}{l}\text { Classroom ini sangat bermanfaat bagi saya dalam } \\
\text { melaksanakan pembelajaran jarak jauh }\end{array}\end{array}$ & $60,5 \%$ & $39,5 \%$ & - & - \\
\hline $\begin{array}{l}\text { Google Classroom sangat membantu saya dalam } \\
\text { melaksanakan pembelajaran jarak jauh }\end{array}$ & $53,5 \%$ & $46,5 \%$ & - & - \\
\hline $\begin{array}{l}\text { Pemanfaatan Google Classroom akan membuat } \\
\text { pembelajaran jarak jauh lebih menarik }\end{array}$ & $63,8 \%$ & $36,2 \%$ & - & - \\
\hline $\begin{array}{l}\text { pemanfaatan Google Classroom akan membuat siswa } \\
\text { menjadi lebih aktif dalam pelaksanaan pembelajaran } \\
\text { jarak jauh }\end{array}$ & $69,2 \%$ & $30,8 \%$ & - & - \\
\hline
\end{tabular}

Pemanfaatan Google Classroom akan meningkatkan $\quad 70,8 \% \quad 29,2 \% \quad-\quad-$
motivasi belajar siswa

Saya akan memanfaatkan Google Classroom untuk $\quad 69,7 \% \quad 30,3 \% \quad-\quad-$
membantu proses pembelajaran walaupun
pembelajaran tatap muka telah dilakukan

Memaksimalkan penggunaan semua fitur Google
$\begin{aligned} & \text { Classroom akan mempermudah saya melaksanakan } \\ & \text { pemeblajaran dalam pembelajaran jarak jauh ini }\end{aligned}$

$\begin{aligned} & \text { Saya lebih mudah memantau kegiatan belajar siswa } \\ & \text { dengan menggunakan Google Classroom }\end{aligned}$
59,5\% $40,5 \% \quad-\quad-$

Pemanfaatan Google Classroom membuat saya lebih
aktif dalam mempersiapkan pembelajaran jarak jauh

\footnotetext{
Saya dapat merancang pembelajaran lebih baik dengan $\quad 70,8 \% \quad 29,2 \% \quad-\quad$ menggunakan Google Classroom
} 
Ket

SS : Sangat Setuju

S : Setuju

TS : Tidak Setuju

STS : Sangat Tidak Setuju

\section{Diskusi}

Pada umumnya peserta pelatihan sudah mengetahui informasi tantang google classroom. Selain itu, beberapa guru pernah menggunakan google classroom dalam pembelajaran daring. Hal ini terlihat dari hasil pre test bahwa rata - rata nilai pre test peserta sebesar 66,7. Hal ini mengindikasikan bahwa peserta telah mengetahui dan atau pernah menggunakan fitur - fitur dalam google classroom. Namun demikian upaya optimalisasi perlu dilakukan dalam upaya pemanfaatan google classroom dalam pembelajaran daring. Menurut Marhamah (2018) kegiatan pelatihan diperlukan dalam upaya meningkatkan kompetensi guru dalam merancang pembelajaran yang kaitannya pada penguasaan teknologi yang adaptif dengan perkembangan saat ini. Hal ini terbukti dengan diadakannya pelatihan optimalisasi pembelajaran daring berbasis google classroom, rata - rata post test peserta meningkat menjadi 85,5 .

Selama proses pelatihan dan pendampingan, peserta terlihat sangat antusias untuk mengeksplor informasi - informasi mengenai penggunaan dan fungsi - fungsi fitur yang yang tersedia di google classroom. Hal ini tergambar dari banyaknya pertanyaan dan tanggapan selama proses pelatihan berlangsung. Hal ini dapat berdampak pada peningkatan kompetensi guru dalam penguasaan terhadap penggunaan google classroom. Menurut Haryanto, et.al (2021) bahwa kegiatan pelatihan pembelajaran daring berbasis aplikasi Google dapat memberikan manfaat bagi guru untuk meningkatkan kemampuan guru di bidang teknologi dan informasi.

Berkaitan dengan hal di atas, pelaksanaan pelatihan dapat dikategorikan berhasil. Hal ini tergambar dari respon peserta pada tabel 1 . 
Respon peserta merupakan hal penting yang menjadi tolak ukur keberhasilan suatu kegiatan. Pada respon peserta dapat terlihat bahwa pelatihan ini sangat bermanfaat dalam merancang pembelajaran serta melalui pelatihan ini, peserta dapat merancang pembelajaran daring lebih baik dengan menggunakan google classroom. Hal ini didukung oleh Samuel (2015) bahwa peningkatan kompetensi guru dipengaruhi oleh intensitas pelatihan yang diikut oleh guru. Dengan demikian kegiatan serupa diperlukan dalam rangka optimalisasi mempersiapkan kegiatan pembelajaran daring.

\section{Kesimpulan}

Berdasarkan kegiatan pengabdian masyarakat ini dapat disimpulkan bahwa kegiatan pelatihan ini peserta pelatihan yaitu guru - guru MGMP IPA Kota Palembang dapat meningkatkan kompetensi mereka dalam upaya merancang pembelajaran daring berbasis google classroom. Melalui pelatihan ini, guru - guru lebih memahami fungsi fitur - fitur yang terdapat dalam google classroom. Dengan demikian guru - guru dapat mengoptimalisasi penerapan google classroom dalam proses pembelajaran daring.

\section{Pengakuan/Acknowledgements}

Kami mengucapkan terimakasih kepada Rektor Universitas Sriwijaya dan Ketua LPPM Unversitas Sriwijaya yang telah mendukung kegiatan Pengabdian Kepada Masyarakat Skema Perkuliahan Desa ini melalui dana DIPA Badan Layanan Umum Universitas Sriwijaya tahun Anggaran 2021. Kami juga mengucapkan terimakasih kepada guru - guru IPA yang tergabung dalam MGMP IPA Kota Palembang yang telah berpartisipasi dalam kegiatan pengabdian ini.

\section{Daftar Referensi}

Harefa, N dan Sumiyati. (2020). Persepsi Siswa terhadap Google Classroom sebagai LMS pada masa Pandemi Covid-19. Science Education and Application Journal. 2(2) 88-100

Haryanto, H., Putra, A. H., Heriansyah, H. (2021). Pelatihan Pembelajaran Daring Berbasis Aplikasi Google Di Masa Pandemik Covid-19 Di SMAN 8 Kota Bengkulu. Dharma Raflesia : Jurnal Ilmiah Pengembangan dan Penerapan IPTEKS, 19 (1), 167 - 176 
Mar'ah, N.K., Rusilowati, A., Sumarni, W. (2020). Perubahan Proses Pembelajaran Daring Pada Siswa Sekolah Dasar Di Tengan Pandemi Covid-19. Prosiding Seminar Nasional Pascasarjana UNNES

Marhamah. (2018). Pentingnya Pengembangan Kompetensi Guru. Bidayah: Studi Ilimu-Ilmu Keislaman, 9 (2), 195 - 216.

Munir. (2009) Pembelajaran Jarak Jauh Berbasis Teknolog ilnformasi dan Komunikasi. Bandung: Alfabeta

Ningsih, S., Kuntarto, E., Kurniawan, A. R. (2020). Teachers' Problems In Using Information And Communication Technology (ICT) And Its Implications In Elementary Schools. Jurnal PAJAR (Pendidikan dan Pengajaran), 4 (3), 518 524.

Sabran, Sabara, E. (2019). Keefektifan Google Classroom sebagai media pembelajaran. PROSIDING SEMINAR NASIONAL LEMBAGA PENELITIAN UNIVERSITAS NEGERI MAKASSAR "Diseminasi Hasil Penelitian melalui Optimalisasi Sinta dan Hak Kekayaan Intelektual"

Salsabila, U.H., Sari, L.I., Lathif, K.H., Lestari, A.P., Ayuning, A. (2020). Peran Teknologi Dalam Pembelajaran Di Masa Pandemicovid-19. Al-Mutharahah: Jurnal Penelitian dan Kajian Sosial Keagamaan, 17 (2), 188 - 198

Samuel, D. (2015). Antusiasme Guru dalam Program Pengembangan Kompetensi Pedagogik Dan Determinannya. Jurnal Kelola, 2 (1), 114 - 121

Soni, Afdhil, H., Regiolina H., Yulia F., Febby A. W., Januar A. A., Evans F., Mitra Unik, Harun Mukhtar,Hasanudd. 2018. "Optimalisasi Pemanfaatan Google Classroom sebagai Media Pembelajaran Di SMK Negeri 1 Bangkinang". Jurnal Pengabdian Untuk Mu NegeRI, 2 (1), 17 - 20 